Review

\title{
Durability of Textile Reinforced Concrete: Existing Knowledge and Current Gaps
}

\author{
Mohammad Alma'aitah ${ }^{1}$, Bahman Ghiassi ${ }^{1, *(D)}$ and Ali Dalalbashi ${ }^{2}$ (D) \\ 1 Centre for Structural Engineering and Informatics, Faculty of Engineering, University of Nottingham, \\ Nottingham NG7 2RD, UK; alyma21@nottingham.ac.uk \\ 2 ISISE, Department of Civil Engineering, University of Minho, 4800-058 Guimarães, Portugal; \\ alidalalbashi@gmail.com \\ * Correspondence: bahman.ghiassi@nottingham.ac.uk
}

Citation: Alma'aitah, M.; Ghiassi, B.; Dalalbashi, A. Durability of Textile Reinforced Concrete: Existing Knowledge and Current Gaps. Appl. Sci. 2021, 11, 2771. https://doi.org/ 10.3390/app11062771

Academic Editor: Gian Piero Lignola

Received: 28 January 2021

Accepted: 16 March 2021

Published: 19 March 2021

Publisher's Note: MDPI stays neutral with regard to jurisdictional claims in published maps and institutional affiliations.

Copyright: (c) 2021 by the authors. Licensee MDPI, Basel, Switzerland. This article is an open access article distributed under the terms and conditions of the Creative Commons Attribution (CC BY) license (https:// creativecommons.org/licenses/by/ $4.0 /)$.

\begin{abstract}
This paper aims to provide a review of the current literature on the durability of textilereinforced concrete and mortar (TRC/TRM) composites. Most previous studies have focused on the role of chemical attacks, freeze-thaw conditions, and high temperatures on the mechanical performance of these composites. Information on the long-term performance of TRCs under synergistic action of mechanical and environmental loads is scarce. Considering the variety of fabrics and matrices used for the production of TRC composites, the existing data are still very limited and comprehensive studies are needed in this field. Additionally, due to the lack of standard procedures, different approaches are often followed for durability or post-ageing mechanical tests, or sufficient data on the curing and post-ageing preparation procedures followed are not provided. These have led to incompatibility of the existing data and in some cases contradictory results on the durability of these materials.
\end{abstract}

Keywords: textile-reinforced concrete (TRC); fabric-reinforced cementitious matrix (FRCM); textilereinforced mortar (TRM); durability

\section{Introduction}

A growing body of research has been devoted to understanding the mechanical response and properties of textile-reinforced concrete (TRC) composites (also referred to as textile-reinforced mortar (TRM) or fibre-reinforced concrete matrix (FRCM) in the literature) [1,2]. These composites are made of continuous fabrics embedded in an inorganic matrix (e.g., cement-based or lime-based mortar) and can show a pseudo ductile response with a high tensile strength when designed appropriately. This makes these composites suitable for the development of novel thin structural components or for the strengthening of existing masonry and concrete structures [3-7]. A disadvantage is that a large portion of this ductility (or crack development) occurs at service load levels (after mortar cracking), thus threatening the reliability and durability at ultimate limit state loads. The addition of short fibres, additives or fibre with different sizing and coatings to the mix design can help in addressing this disadvantage to some extent [8], but further investigations in this field are still needed. The current understanding of the mechanical response of these composites is reaching an advanced stage, but existing knowledge on the long-term performance and durability of these composites is still limited [9].

Durability is defined as the ability of material or components to resist loads without failure during their service life [10]. For the structural application of TRCs, long-term strain capacity, transport properties (in both cracked and uncracked states) and resistance to aggressive environments are the most critical durability indicators [10]. It is generally believed that TRCs show better durability than conventional reinforced concrete [8]. However, there is still a lack of sufficient experimental or field evidence for this debate. Considering the variety of existing textile and matrix types, the durability of TRCs is also 
expected to vary significantly, hence the need for comprehensive investigations in the coming years. The service cracking pattern and width can have a significant influence on the long-term performance of TRCs. As a criterion, limiting the crack widths to less than $50 \mu \mathrm{m}$ is suggested to avoid penetrating deteriorating materials into TRC composites [8].

A growing number of publications can be found in the literature on the evaluation of the durability of TRC (and TRM) composites. These studies are mainly focused on the effect of chemical attacks, freeze-thaw cycles, or high temperatures on the mechanical response of TRC composites. Aiming at highlighting the gaps in this field and uncertainties on the existing data, a brief overview of these studies is presented in this paper.

\section{Durability}

\subsection{Chemical Attack}

The existing literature mainly focuses on the influence of alkaline, saline, and acid solution attack on the mechanical properties of TRC composites [11-20], as presented in Table 1.

Table 1. Summary of literature on chemical attack.

\begin{tabular}{|c|c|c|c|c|c|c|c|}
\hline Ref. & Fibre & Matrix & Standard & Methodology & Solution & Duration & $\begin{array}{l}\text { Post-Exposed } \\
\text { Tests }\end{array}$ \\
\hline \multirow[b]{2}{*}{ [13] } & \multirow[b]{2}{*}{$\begin{array}{l}\text { carbon and } \\
\mathrm{PBO}^{*}\end{array}$} & \multirow[b]{2}{*}{ cement } & \multirow[b]{2}{*}{ AC434 } & \multirow[b]{2}{*}{ immersion } & $\begin{array}{l}\text { saline } \\
\text { (ocean) }\end{array}$ & \multirow[b]{2}{*}{$\begin{array}{c}1000 \text { and } \\
3000 \text { h at } 22^{\circ} \mathrm{C}\end{array}$} & \multirow[b]{2}{*}{$\begin{array}{l}\text { tensile and } \\
\text { pull-off }\end{array}$} \\
\hline & & & & & $\begin{array}{c}\text { alkaline } \\
\left(\mathrm{Ca}(\mathrm{OH})_{2}+\mathrm{NaOH}+\mathrm{KOH}\right. \\
\mathrm{pH}>12.5)\end{array}$ & & \\
\hline \multirow{2}{*}{ [11] } & \multirow{2}{*}{ glass } & \multirow{2}{*}{$\begin{array}{l}\text { HPC } \\
\text { cement }\end{array}$} & \multirow{2}{*}{$\begin{array}{l}\text { JSCE-E } \\
549-2000\end{array}$} & \multirow{2}{*}{ immersion } & $\begin{array}{c}\text { alkaline } \\
(10 \% \mathrm{NaOH}, \mathrm{pH}=13)\end{array}$ & \multirow{2}{*}{$1440 \mathrm{~h}$} & \multirow{2}{*}{ tensile } \\
\hline & & & & & $\begin{array}{c}\text { acidic } \\
\left(10 \% \mathrm{H}_{2} \mathrm{SO}_{4}, \mathrm{pH}=0.2 \text { to } 3.4\right)\end{array}$ & & \\
\hline [14] & $\begin{array}{c}\text { E-glass, } \\
\text { AR-glass **, } \\
\text { carbon, basalt, } \\
\text { PBO, steel }\end{array}$ & - & $\begin{array}{l}\text { ASTM E2098 } \\
\text { ETAG } 029\end{array}$ & immersion & $\begin{array}{c}\text { alkaline } \\
\left(16 \% \mathrm{Ca}(\mathrm{OH})_{2}, \mathrm{pH}=12.6\right) \\
\left(16 \% \mathrm{Ca}(\mathrm{OH})_{2}+1 \% \mathrm{NaOH}+\right. \\
1.4 \% \mathrm{KOH}, \mathrm{pH}=13) \\
(0.2 \% \mathrm{KOH}, \mathrm{pH}=12.5) \\
\left(5 \% \mathrm{Ca}(\mathrm{OH})_{2}, \mathrm{pH}=14\right)\end{array}$ & $\begin{array}{l}168,720,1440 \\
2160 \text { and } \\
4320 \mathrm{~h} \text { at } 20 \\
\text { and } 45^{\circ} \mathrm{C}\end{array}$ & tensile \\
\hline [12] & $\begin{array}{l}\text { hybrid fabric } \\
\text { (carbon and } \\
\text { E-glass) }\end{array}$ & concrete & $\begin{array}{c}\mathrm{GB} / \mathrm{T} \\
50082-2009\end{array}$ & wet-dry & $\begin{array}{c}\text { saline } \\
(5 \% \mathrm{NaCl})\end{array}$ & $\begin{array}{c}\text { 90, } 120 \text { and } \\
150 \text { cycles } \\
\text { (each cycle } \\
\text { includes } 12 \mathrm{~h} \\
\text { wet and } 12 \mathrm{~h} \\
\text { dry) }\end{array}$ & $\begin{array}{l}\text { pull-out and } \\
\text { flexural }\end{array}$ \\
\hline \multirow[b]{2}{*}{ [15] } & \multirow[b]{2}{*}{ AR-glass } & \multirow[b]{2}{*}{ lime } & \multirow[b]{2}{*}{ ASTM D7705 } & immersion & \multirow[b]{2}{*}{$\begin{array}{c}\text { saline } \\
(3.5 \% \mathrm{NaCl})\end{array}$} & $1000 \mathrm{~h}$ at $60^{\circ} \mathrm{C}$ & \\
\hline & & & & wet-dry & & $\begin{array}{l}10 \text { cycles (each } \\
\text { cycle includes } \\
2 \text { days wet and } \\
2 \text { days dry at } \\
60^{\circ} \mathrm{C} \text { ) }\end{array}$ & single-lap \\
\hline [16] & carbon & $\begin{array}{l}\text { cement, } \\
\text { lime }\end{array}$ & $\begin{array}{l}\text { RILEM MS A.1, } \\
1998\end{array}$ & wet-dry & $\begin{array}{c}\text { saline } \\
\left(10 \% \mathrm{Na}_{2} \mathrm{SO}_{4}\right)\end{array}$ & 11 cycles & pull-off \\
\hline \multirow{2}{*}{ [17] } & \multirow{2}{*}{ AR-glass } & \multirow{2}{*}{$\begin{array}{l}\text { hydrated } \\
\text { and air lie }\end{array}$} & \multirow{2}{*}{-} & \multirow{2}{*}{ immersion } & $\begin{array}{c}\text { saline } \\
(3.5 \% \mathrm{NaCl})\end{array}$ & \multirow{2}{*}{$1000 \mathrm{~h}$ at $23^{\circ} \mathrm{C}$} & \multirow{2}{*}{ tensile } \\
\hline & & & & & $\begin{array}{c}\text { alkaline } \\
\left(\mathrm{NaHCO}_{3}, \mathrm{pH}=10\right)\end{array}$ & & \\
\hline
\end{tabular}


Table 1. Cont.

\begin{tabular}{|c|c|c|c|c|c|c|c|}
\hline Ref. & Fibre & Matrix & Standard & Methodology & Solution & Duration & $\begin{array}{l}\text { Post-Exposed } \\
\text { Tests }\end{array}$ \\
\hline \multirow{3}{*}{ [18] } & \multirow{3}{*}{ carbon } & \multirow{3}{*}{ pozzolan } & \multirow{3}{*}{-} & \multirow{3}{*}{ immersion } & $\begin{array}{c}\text { saline } \\
(3.5 \% \mathrm{NaCl})\end{array}$ & \multirow{3}{*}{$1000 \mathrm{~h}$} & \multirow{3}{*}{ tensile } \\
\hline & & & & & $\begin{array}{c}\text { alkaline } \\
\left(\mathrm{NaHCO}_{3}, \mathrm{pH}=10\right)\end{array}$ & & \\
\hline & & & & & $\begin{array}{c}\text { acidic } \\
(\mathrm{HCl}, \mathrm{pH}=2.5)\end{array}$ & & \\
\hline [19] & steel & $\begin{array}{c}\text { lime and } \\
\text { cement }\end{array}$ & - & wet-dry & $\begin{array}{c}\text { saline } \\
(2 \% \mathrm{NaCl}+8 \% \\
\left.\mathrm{Na}_{2} \mathrm{SO}_{4} \cdot 10 \mathrm{H}_{2} \mathrm{O}\right)\end{array}$ & $\begin{array}{l}\text { Six cycles (each } \\
\text { cycle includes } \\
2 \text { days wet by } \\
\text { capillary and } \\
3 \text { days dry at } \\
60^{\circ} \mathrm{C} \text { ) }\end{array}$ & single-lap \\
\hline \multirow{2}{*}{ [20] } & \multirow{2}{*}{ AR-glass } & \multirow{2}{*}{ cement } & \multirow{2}{*}{$\begin{array}{c}\text { ASTM } \\
\text { D1141-98 }\end{array}$} & \multirow{2}{*}{ immersion } & $\begin{array}{c}\text { saline } \\
\left(2.45 \% \mathrm{NaCl}+0.41 \% \mathrm{Na}_{2} \mathrm{SO}_{4}\right)\end{array}$ & \multirow{2}{*}{$1000 \mathrm{~h}$ at $40^{\circ} \mathrm{C}$} & \multirow{2}{*}{ tensile } \\
\hline & & & & & $\begin{array}{c}\text { alkaline } \\
((4 \% \mathrm{NaOH}, \mathrm{pH}=13)\end{array}$ & & \\
\hline
\end{tabular}

* PBO: polyparaphenylene benzobisoxazole; ${ }^{* *}$ AR-glass: Alkali-resistant glass.

Due to the lack of well-established standard procedures, various procedures have been followed, including immersing samples in a solution under different temperatures or concentration level or subjecting them to wet-dry cycles. Most studies have considered the role of alkaline environment, and only a few studies can be found on the effect of saline or acidic environments. In most studies, tensile tests are used to evaluate the changes in mechanical performance after exposure $[11,13,17,18,20]$, and flexural tests [12] or the fibre-to-matrix bond tests [12] are the least popular. A few studies have also considered the changes of the bond strength between TRC as a repair material and a substrate (concrete or masonry) through pull-off [16] or single lap shear tests [19].

Carbon and glass are the most common studied fabrics, and less attention is given to steel, basalt, PBO or natural fibres, which are of most interest in strengthening applications. The type of fibre and coating used plays an essential role in the residual mechanical performance of TRC/TRMs, but the existing information in this field is still limited. Carbon fibres are generally considered the most resistant to chemical attack $[8,13,14,18,21]$. Steel fibres are durable under alkaline conditions [14] but can corrode under saline environments [19]. Glass and basalt fibres are the most susceptible to alkaline environments and for this reason have been the subject of most existing studies. Application of alkali-resistant coatings is often considered for enhancing the performance of these fibres to alkaline environments [14], but this leads to a significant increase in their price. It is known that coating E-glass (usually with Zirconium dioxide to produce AR-glass) helps in improving the resistance of glass fibres to alkaline environments $[11,14,22]$. However, the scientific evidence on the efficiency of the existing coatings is still limited, and few studies can also be found showing the susceptibility of proposed coating materials [23]. Additionally, different studies have used different alkaline solutions ( $\mathrm{pH}$ levels), which makes comparison between different databases complicated. As for the matrix, most studies have focused on ordinary cement-based matrices, and fewer studies are available on blended cements, novel low-carbon cements or lime-based mortars.

The experimental results are sometimes contradictory. In some cases, an improvement of the mechanical response (tensile strength) is reported after exposure to saline and alkaline conditions, which is attributed to continuous hydration of the matrix after 28 days [13], while others reported deterioration of the mechanical response of cement-based TRC [20] even when alkali-resistant glass fabrics [11] or lime-based TRCs (the results also depend on the type of lime-based mortar) [17] were used. The results are also contradictory with respect to acidic solution environments. While some studies show suitable resistance, others show a significant vulnerability under acidic environments [11]. The type of mechanical 
tests performed after ageing and the test setups used also have a significant influence on the obtained results but the available information on this is still very limited. For example, while no deterioration of the tensile strength was observed after exposure to chemical attacks in some cases, the flexural strength was observed to deteriorate. This can be attributed to the role of boundary conditions on the durability test results [14]. The vulnerability of bond strength and failure mode to alkaline and saline environments, characterised by pull-off [13,16] or single-lap shear tests [15], also can be highly affected by the test setup used. Two critical factors that have not been discussed or investigated yet are the role of curing conditions and of post-ageing conditioning of the samples before performing mechanical tests. Additionally, most reported experimental results do not contain this information, making analysis and comparison of the data from different labs complicated.

\subsection{Frost (Freeze-Thaw) Attack}

The existing studies on the effect of frost attack on the mechanical performance of TRCs $[8,10-13,24,25]$ are summarised in Table 2.

Table 2. Summary of literature on frost attack.

\begin{tabular}{|c|c|c|c|c|c|c|}
\hline Ref. & Fibre & Matrix & Standard & Conditions & Duration & $\begin{array}{l}\text { Post-Exposed } \\
\text { Tests Test }\end{array}$ \\
\hline [13] & $\begin{array}{l}\text { carbon and } \\
\text { PBO }\end{array}$ & cement & AC434 & $\begin{array}{l}-18^{\circ} \mathrm{C} \leftrightarrow 37.7^{\circ} \mathrm{C} \\
(100 \% \mathrm{RH})\end{array}$ & $\begin{array}{l}20 \text { cycles ( } 4 \mathrm{~h} \text { freezing } \\
\text { and } 12 \mathrm{~h} \text { thawing) }\end{array}$ & tensile \\
\hline [11] & glass & concrete & CSN 731322 & $\begin{array}{l}-18^{\circ} \mathrm{C} \leftrightarrow 20^{\circ} \mathrm{C} \\
\text { (immersing in } \\
\text { water) }\end{array}$ & $\begin{array}{l}\text { 50, } 100 \text { and } 150 \text { cycles } \\
\text { (4 h freezing and } 2 \mathrm{~h} \\
\text { thawing) }\end{array}$ & tensile \\
\hline [12] & $\begin{array}{l}\text { hybrid fabric } \\
\text { (carbon and } \\
\text { E-glass) }\end{array}$ & concrete & $\begin{array}{c}\mathrm{GB} / \mathrm{T} \\
50082-2009\end{array}$ & $\begin{array}{l}-18^{\circ} \mathrm{C} \leftrightarrow 5^{\circ} \mathrm{C} \\
\text { immersing in saline } \\
{[5 \% \mathrm{NaCl}]}\end{array}$ & $\begin{array}{l}50,70 \text { and } 90 \text { cycles ( } 3 \mathrm{~h} \\
\text { freezing and thawing) }\end{array}$ & $\begin{array}{l}\text { pull-out and } \\
\text { flexural }\end{array}$ \\
\hline [24] & AR-glass & cement & ASTM C666 & $\begin{array}{l}-18^{\circ} \mathrm{C} \leftrightarrow 4^{\circ} \mathrm{C} \\
(100 \% \mathrm{RH})\end{array}$ & $\begin{array}{l}25,50,100,150 \text { and } \\
500 \text { cycles ( } 30 \mathrm{~min} \\
\text { freezing and } 30 \mathrm{~min} \\
\text { thawing) }\end{array}$ & tensile \\
\hline [26] & AR-glass & cement & NBN EN 12467 & $\begin{array}{l}-20^{\circ} \mathrm{C} \leftrightarrow 20^{\circ} \mathrm{C} \\
(100 \% \mathrm{RH})\end{array}$ & $\begin{array}{l}50 \text { cycles ( } 2 \mathrm{~h} \text { freezing } \\
\text { and } 2 \mathrm{~h} \text { thawing) }\end{array}$ & tensile \\
\hline [18] & carbon & lime & AC434 & $\begin{array}{l}-18{ }^{\circ} \mathrm{C} \leftrightarrow 37.7^{\circ} \mathrm{C} \\
(100 \% \mathrm{RH})\end{array}$ & $\begin{array}{l}20 \text { cycles ( } 4 \mathrm{~h} \text { freezing } \\
\text { and } 12 \mathrm{~h} \text { thawing) }\end{array}$ & tensile \\
\hline [16] & carbon & $\begin{array}{l}\text { cement, } \\
\text { lime }\end{array}$ & - & $\begin{array}{l}-10^{\circ} \mathrm{C} \leftrightarrow 70^{\circ} \mathrm{C} \\
(60 \% \mathrm{RH})\end{array}$ & $\begin{array}{l}40 \text { cycles ( } 3 \mathrm{~h} \text { freezing } \\
\text { and } 3 \mathrm{~h} \text { thawing) }\end{array}$ & pull-off \\
\hline [27] & glass & lime & - & $\begin{array}{l}-20^{\circ} \mathrm{C} \leftrightarrow 25^{\circ} \mathrm{C} \\
(100 \% \mathrm{RH})\end{array}$ & $\begin{array}{l}14 \text { cycles ( } 6 \mathrm{~h} \text { freezing } \\
\text { and } 2 \mathrm{~h} \text { thawing) }\end{array}$ & $\begin{array}{l}\text { tensile and } \\
\text { flexural }\end{array}$ \\
\hline [28] & steel & cement & ASTM C666 & $\begin{array}{l}-18^{\circ} \mathrm{C} \leftrightarrow 4^{\circ} \mathrm{C} \\
(100 \% \mathrm{RH})\end{array}$ & $\begin{array}{l}100 \text { cycles }(30 \mathrm{~min} \\
\text { freezing and } 30 \mathrm{~min} \\
\text { thawing) }\end{array}$ & pull-out \\
\hline [20] & AR-glass & cement & - & $\begin{array}{l}-18^{\circ} \mathrm{C} \leftrightarrow 40^{\circ} \mathrm{C} \\
(100 \% \mathrm{RH})\end{array}$ & $\begin{array}{l}40 \text { cycles ( } 12 \mathrm{~h} \text { freezing } \\
\text { and } 12 \mathrm{~h} \text { thawing) }\end{array}$ & tensile \\
\hline [29] & AR-glass & lime & - & $\begin{array}{l}-10^{\circ} \mathrm{C} \leftrightarrow 30^{\circ} \mathrm{C} \\
(90 \% \mathrm{RH})\end{array}$ & $\begin{array}{l}360 \text { cycles }(2 \mathrm{~h} \text { freezing } \\
\text { and } 2 \mathrm{~h} \text { thawing) }\end{array}$ & pull-out \\
\hline
\end{tabular}

Freeze-thaw conditions can lead to degradation and reduction of the cracking strength of the matrix, deterioration of the bond between the textile and the matrix (either due to thermal incompatibility between fibre and matrix or due to expansion of the water volume after freezing) and even deterioration of the textile (depending on the presence and type of coating). The deterioration level observed is therefore highly influenced by the 
strength of the matrix, the textile-to-matrix bond, boundary conditions and the exposure conditions (the temperature level, the number of cycles, and the degree of saturation of the matrix). Again, due to the lack of well-established standards for evaluating the freeze-thaw resistance of TRC composites, various researchers used different protocols and number of cycles, which makes performing critical comparisons between different experimental databases impossible. The selected mechanical post ageing tests also vary in some cases, although tensile tests remain the most popular.

The results are again contradictory in some cases. A few studies, e.g., [13,18], show enhancement of the tensile behaviour under FT conditions, which could be attributed to hydration of the matrix, while some show a reduction of the cracking load [11] or the tensile strength, flexural strength or fracture toughness [20,24,26,27]. Among these, the changes in the textile-to-matrix or TRC-to-substrate was investigated only in a few studies [16]. Again, the results are sometimes contradictory, some studies showing the degradation of the bond behaviour [12], some reported no changes [28] and some reported its enhancement [29].

The existing data in this field are still very limited, and the role of different parameters, including matrix type, fabric type, fabric configuration, reinforcement ratio, matrix thickness, etc., on freeze-thaw performance, is unknown. Again, the role of curing conditions and post-ageing samples conditions and mechanical test setups on the experimental observations is not clear.

\subsection{High Temperature}

A summary of previous studies performed on the effect of high temperatures on the performance of TRC composites is presented in Tables 3 and 4. These studies can be generally categorised into two groups: (i) high-temperature vapour exposure or hightemperature immersion tests and (ii) high-air-temperature exposure tests. A brief overview of each category is presented next.

Table 3. Summary of literature on immersion in hot water or exposure to high-temperature vapour.

\begin{tabular}{cccccccc}
\hline Ref. & Fibre & Matrix & Standard & Methodology & Condition & Duration & Post-Exposed Tests \\
\hline$[13]$ & $\begin{array}{c}\text { carbon and } \\
\text { PBO }\end{array}$ & cement & AC434 & immersion & $37.7^{\circ} \mathrm{C}$ & 1000 and $3000 \mathrm{~h}$ & tensile and pull-off \\
\hline$[26]$ & AR-glass & cement & $\begin{array}{c}\text { NBN EN } \\
12467\end{array}$ & $\begin{array}{c}\text { heat-rain } \\
\text { cycle }\end{array}$ & $60{ }^{\circ} \mathrm{C} \leftrightarrow 15^{\circ} \mathrm{C}$ & $\begin{array}{c}50 \text { cycles (each cycle } \\
\text { includes } 45 \text { min heat } \\
\text { and } 15 \text { min rain) }\end{array}$ & tensile \\
\hline$[30]$ & AR-glass & concrete & - & fog room & $40{ }^{\circ} \mathrm{C}$ & $\begin{array}{c}672,1344,2160,4320 \\
\text { and } 8760 \mathrm{~h}\end{array}$ & pull-out \\
\hline$[31]$ & AR-glass & mineral & - & immersion & $50^{\circ} \mathrm{C}$ & 336,2160 and $2880 \mathrm{~h}$ & tensile and flexural \\
\hline
\end{tabular}

Table 4. Summary of literature on effect of elevated temperatures.

\begin{tabular}{|c|c|c|c|c|c|c|}
\hline Ref. & Fibre & Matrix & Standard & Conditions & Duration & Post-Exposed Tests \\
\hline$[32]$ & carbon & cement & - & $\begin{array}{l}100,150,200,400 \\
\text { and } 600^{\circ} \mathrm{C}\end{array}$ & $120 \mathrm{~min}$ & $\begin{array}{l}\text { pull-out after } \\
\text { cooling to } 20^{\circ} \mathrm{C}\end{array}$ \\
\hline$[33]$ & basalt & concrete & - & $\begin{array}{c}75,150,200,300,400 \\
600 \text { and } 1000{ }^{\circ} \mathrm{C}\end{array}$ & $60 \mathrm{~min}$ & tensile after cooling \\
\hline \multirow{3}{*}[34]{} & \multirow{3}{*}{ carbon } & \multirow{3}{*}{ cement } & \multirow{3}{*}{-} & 20,80 and $120^{\circ} \mathrm{C}$ & $100 \mathrm{~min}$ & tensile after heating \\
\hline & & & & \multirow{2}{*}{$120^{\circ} \mathrm{C}$} & $100 \mathrm{~min}$ & \multirow{2}{*}{$\begin{array}{l}\text { double-shear after } \\
\text { cooling to } 20^{\circ} \mathrm{C}\end{array}$} \\
\hline & & & & & $60 \mathrm{~min}$ & \\
\hline$[35]$ & AR-glass & cement & - & $\begin{array}{c}20,75,150,300,400 \\
\text { and } 600{ }^{\circ} \mathrm{C}\end{array}$ & $60 \mathrm{~min}$ & $\begin{array}{c}\text { tensile after cooling } \\
\text { to } 20^{\circ} \mathrm{C}\end{array}$ \\
\hline
\end{tabular}


Table 4. Cont.

\begin{tabular}{|c|c|c|c|c|c|c|}
\hline Ref. & Fibre & Matrix & Standard & Conditions & Duration & Post-Exposed Tests \\
\hline \multirow{2}{*}{ [36] } & AR-glass & \multirow{2}{*}{ cement } & \multirow{2}{*}{-} & \multirow{2}{*}{100,300 and $600^{\circ} \mathrm{C}$} & \multirow{2}{*}{$120 \mathrm{~min}$} & \multirow{2}{*}{$\begin{array}{l}\text { pull-out after } \\
\text { cooling to } 20^{\circ} \mathrm{C}\end{array}$} \\
\hline & basalt & & & & & \\
\hline$[37]$ & $\begin{array}{l}\text { AR-glass and } \\
\text { carbon }\end{array}$ & cement & EN 1363-1 & $\sim 850^{\circ} \mathrm{C}$ & 15 and $30 \mathrm{~min}$ & $\begin{array}{l}\text { flexural test after } \\
\text { cooling }\end{array}$ \\
\hline \multirow{2}{*}{ [38] } & E-glass & \multirow{2}{*}{ cement } & \multirow{2}{*}{-} & \multirow{2}{*}{$\begin{array}{c}200,400,600 \text { and } \\
800{ }^{\circ} \mathrm{C}\end{array}$} & \multirow{2}{*}{$60 \mathrm{~min}$} & \multirow{2}{*}{$\begin{array}{l}\text { flexural test after } \\
\text { cooling }\end{array}$} \\
\hline & carbon & & & & & \\
\hline \multirow{3}{*}{ [39] } & PBO & \multirow{3}{*}{ cement } & \multirow{3}{*}{-} & \multirow{3}{*}{$\begin{array}{c}20,100,150 \text { and } \\
200^{\circ} \mathrm{C}\end{array}$} & \multirow{3}{*}{$180 \mathrm{~min}$} & \multirow{3}{*}{$\begin{array}{l}\text { single-lap after } \\
\text { cooling }\end{array}$} \\
\hline & basalt & & & & & \\
\hline & steel & & & & & \\
\hline$[40]$ & AR-glass & cement & - & 100,200 and $300^{\circ} \mathrm{C}$ & $60 \mathrm{~min}$ & $\begin{array}{l}\text { single-lap after } \\
\text { cooling }\end{array}$ \\
\hline [41] & AR-glass & cement & - & $\begin{array}{c}20,75,150,300,400 \\
\text { and } 600{ }^{\circ} \mathrm{C}\end{array}$ & $60 \mathrm{~min}$ & $\begin{array}{l}\text { tensile at elevated } \\
\text { temperature }\end{array}$ \\
\hline
\end{tabular}

\subsubsection{Effect of Hot Water or Vapour}

The effect of hot water $\left(<60^{\circ} \mathrm{C}\right)$ or vapour on the mechanical properties of TRC composites was investigated in a few studies $[13,26,30,31]$. These conditions can lead to different deterioration mechanisms. On one hand, hydration of cement can be enhanced leading to the formation of CSH phases at the textile-to-matrix interface [30]. Depending on the alkalinity of the pore solution and the type of textile and its coating, these hydration products can improve the bond between the textile and matrix or penetrate the filaments causing damage and reducing the tensile strength $[1,3,19]$. Immersion in high-temperature water or solutions is often used for the characterization of the activation energy corresponding to a certain degradation mechanism (e.g., alkaline attack). However, it should be noted that high-temperature moisture or vapour can cause deterioration of the fabric coating (especially when epoxy-based coatings are used) and consequently of the composite performance, and this can lead to inaccurate conclusions.

\subsubsection{Effect of Elevated Air Temperature}

Studies on the role of elevated temperatures, which are limited and mostly focused on cement-based mortars, can be divided into, see Table 4, (i) studies in which understanding the residual mechanical properties after exposure to high temperatures is of concern and (ii) studies in which the objective is to understand the mechanical performance of TRC composites under different temperatures. The first category of studies is usually performed by exposure of samples to the desired temperatures and for different exposure times. After that, the specimens are cooled down to room temperature and then mechanically tested. In the second category of studies, the specimens are tested under the desired temperature. These studies are usually followed by exposure of the samples (under clamped or unclamped conditions) to the desired temperature and then application of mechanical loads while keeping the temperature constant. Again, tensile tests remain the most popular post-ageing characterization test method, and there is a lack of comprehensive studies on the textile-to-matrix and TRC-to-substrate bond response. The considered exposure periods and temperature levels also vary significantly.

It is clear that high temperatures can lead to deterioration of TRC composites [32-42], although in some cases an enhancement of the tensile and bond strength is reported up until to $150-200{ }^{\circ} \mathrm{C}[32,33,35,41]$. After this point and by increasing the temperature up to $600{ }^{\circ} \mathrm{C}$, the TRC degradation signs were revealed because of the coatings thermal decomposition and the dehydration of the matrix [33]. Additionally, it was reported 
that the high temperature can lead to a change of failure mode; textile degradation; and degradation of the textile-to-mortar interface $[36,39,40]$.

\section{Factors Influencing the Durability and Mechanical Performance}

\subsection{Short Fibres}

There is a growing body of literature that recognises the importance of adding short fibres to TRC composites. It is known that adding short fibres can enhance the cracking strength, crack patterns, crack spacing and mechanical performance of mortar $[5,13,26]$, but in the case of TRCs, the field is still very limited. The vast literature in the field of strain hardening composites can be used in this field to enhance the service performance of these composites. Among the few existing studies, it has been observed that short fibres can reduce the transport properties and shrinkage of concrete [43]. Resistance against frost attack or high-temperature has also been reported to be improved [41] when fibre volume fraction is at an optimum level as high volumes of short fibres can adversely affect the viscosity of concrete, the distribution of fibres in the matrix, the workability of concrete, and its porosity [44,45]. Further investigations on the optimum amount of fibres to be used, the type of fibres and its effects on mechanics and durability of TRC composites is needed and proposed for future studies.

\subsection{Additives}

The matrix of TRCs usually consists of cement, fine grade sand, water and plasticisers. Due to the lack of coarse aggregates, the cement content in the matrix is usually higher than conventional concrete for achieving the same concrete class. Replacement of cement with mineral additives such as silica fume, fly ash and metakaolin has naturally been considered in some studies [8], but research in this field is still limited. The water-binder ratio, which can play an essential role on the durability of the matrix and the composite system $[8,10,12]$, is also usually higher in these composites (to enhance workability). The addition of fly ash, metakaolin, silica fume and blast furnace slag can reduce the alkalinity of the cement pore solution [8] or enhancement of the self-healing properties [46], thus enhancing the durability of glass-based TRCs against alkaline corrosion. Mobasher et al. [47] showed the addition of fly ash ( $60 \%$ replacement with cement) and $5 \%$ silica fume could enhance the mechanical properties of AR-glass TRCs by increasing the density of the matrix and decreasing the calcium hydroxide at the interface transition zone [47]. Silica fume addition has an apparent effect on the strength and permeability of the matrix $[5,13,32,33]$. A combination of Metakaolin and fly ash was also found to have a significant influence on the long-term durability of TRCs [30].

\subsection{Sizing and Coating}

Sizing is added to the filament/fibre surface during the spinning process to reduce the damage potential during processing and handling and improve the fibres tensile efficiency. After sizing, the filament, bundle and fabric surfaces can be coated [8]. There is a large and growing body of literature investigating the effect of sizing and coating on the mechanical performance and durability of TRCs [48-53]. The existing literature is still limited but shows sizing and coating could improve the bond between filaments and increase load-bearing performance $[5,38,39]$. The type of coating (e.g., epoxy, micro-sized silica or nano-sized silica) could also significantly influence the bond and mechanical properties of TRCs [53]. The coating can also affect the transport properties of TRC composite, hinder the chemical attack of the fabric in the alkaline environment, maintain the fabric's properties during the service life $[5,38,39,54]$, affect the thermomechanical behaviour of TRCs $[13,32,37]$ or reduce the deposition of hydration products between the filaments [10]. 


\section{Conclusions}

This paper aimed to provide a review of the existing literature on the durability of textile-reinforced concrete and mortars (referred to as TRC, TRM or FRCM in the literature) under aggressive environmental conditions. Overall, the following observations are made:

- The existing data on the durability of TRC composites, although growing, remains limited. Most previous studies have focused on chemical attacks, freeze-thaw and hightemperature effects. The role of the synergistic action of mechanical and environmental loads remains very poorly addressed. Considering the variety of existing textile and matrix types, the durability of TRCs is expected to vary significantly, hence the need for more comprehensive investigations in this field.

- Due to the lack of standard durability test methods, different test procedures or environmental conditions are often followed by different researchers. As a result, some of the existing data are not comparable. Additionally, the reported data often lack sufficient information on the procedures followed especially the curing conditions and period (especially important when lime-based mortars are used) or the preparation procedure followed after environmental exposure and before performing the postageing tests (e.g., were the tests performed immediately after exposure or after a while. If latter was followed, how this was controlled).

- In most of the previous tests, tensile tests are used as a macro mechanical characterization method to evaluate the changes in performance after exposure to environmental conditions. Micro-mechanical test data (e.g., pull-out test results) are still very scarce but needed for better understanding the underlying deterioration mechanisms. In tensile tests data, sometimes different test setups are used making the results incomparable. Additionally, the results from tensile tests do not have good repeatability and are not representative of the actual field behaviour in many cases (this also depends on the gripping mechanism used). To consider these factors, flexural tests are suggested to be considered for future studies. Flexural tests are simple to perform and have better repeatability. The round-robin tests planned in the framework of the RILEM TC 20-IMC is expected to address a significant part of these concerns.

Author Contributions: Conceptualization, methodology, literature review, analysis of data, writing, revision and editing, M.A., B.G. and A.D.; supervision, B.G.; project administration, B.G.; funding acquisition, B.G. All authors have read and agreed to the published version of the manuscript.

Funding: The support to the third author through grant SFRH/BD/131282/2017 is acknowledged.

Institutional Review Board Statement: Not applicable.

Informed Consent Statement: Not applicable.

Data Availability Statement: Not applicable.

Conflicts of Interest: The authors declare no conflict of interest.

\section{References}

1. De Santis, S.; Ceroni, F.; de Felice, G.; Fagone, M.; Ghiassi, B.; Kwiecień, A.; Lignola, G.P.; Morganti, M.; Santandrea, M.; Valluzzi, M.R.; et al. Round Robin Test on tensile and bond behaviour of Steel Reinforced Grout systems. Compos. Part B Eng. 2017, 127, 100-120. [CrossRef]

2. Wang, X.; Lam, C.C.; Iu, V.P. Bond behaviour of steel-TRM composites for strengthening masonry elements: Experimental testing and numerical modelling. Constr. Build. Mater. 2020, 253, 119157. [CrossRef]

3. Ombres, L.; Verre, S. Structural behaviour of fabric reinforced cementitious matrix (FRCM) strengthened concrete columns under eccentric loading. Compos. Part B 2015, 75, 235-249. [CrossRef]

4. Raoof, S.M.; Koutas, L.N.; Bournas, D.A. Textile-reinforced mortar (TRM) versus fibre-reinforced polymers (FRP) in flexural strengthening of RC beams. Constr. Build. Mater. 2017, 151, 279-291. [CrossRef]

5. De Santis, S.; Roscini, F.; de Felice, G. Full-scale tests on masonry vaults strengthened with Steel Reinforced Grout. Compos. Part B Eng. 2018, 141, 20-36. [CrossRef]

6. Shabdin, M.; Zargaran, M.; Attari, N.K.A. Experimental diagonal tension (shear) test of Un-Reinforced Masonry (URM) walls strengthened with textile reinforced mortar (TRM). Constr. Build. Mater. 2018, 164, 704-715. [CrossRef] 
7. Minafò, G.; La Mendola, L. Experimental investigation on the effect of mortar grade on the compressive behaviour of FRCM confined masonry columns. Compos. Part B Eng. 2018, 146, 1-12. [CrossRef]

8. Peled, A.; Bentur, A.; Mobasher, B. Textile Reinforced Concrete, 1st ed.; Mindess, S., Bentur, A., Eds.; CRC Press: Boca Raton, FL, USA, August 2017; ISBN 9781466552555.

9. Ghiassi, B. Mechanics and durability of textile reinforced mortars: A review of recent advances and open issues. RILEM Tech. Lett. 2019, 4, 130-137. [CrossRef]

10. Mechtcherine, V. Towards a durability framework for structural elements and structures made of or strengthened with highperformance fibre-reinforced composites. Constr. Build. Mater. 2012, 31, 94-104. [CrossRef]

11. Machovec, J.; Reiterman, P. Influence of aggressive environment on the tensile properties of textile reinforced concrete. Acta Polytech. 2018, 58, 245-252. [CrossRef]

12. Yin, S.; Jing, L.; Yin, M.; Wang, B. Mechanical properties of textile reinforced concrete under chloride wet-dry and freeze-thaw cycle environments. Cem. Concr. Compos. 2019, 96, 118-127. [CrossRef]

13. Arboleda, D.; Babaeidarabad, S.; Hays, C.D.; Nanni, A. Durability of fabric reinforced cementitious matrix (FRCM) composites. In Proceedings of the 7th International Conference of FRP Composites in Civil Engineering (CICE 2014), Vancouver, BC, Canada, 20-22 August 2014; pp. 1-6.

14. Micelli, F.; Aiello, M.A. Residual tensile strength of dry and impregnated reinforcement fi bres after exposure to alkaline environments. Compos. Part B 2017, 159, 490-501. [CrossRef]

15. Donnini, J. Durability of glass FRCM systems: Effects of different environments on mechanical properties. Compos. Part B 2019, 174, 107047. [CrossRef]

16. Tedeschi, C.; Perego, S.; Milano, P. Study on Local Effects of Aggressive Environmental Conditions on Masonry Strengthened with FRCM. In Brick and Block Masonry. Trends, Innovation and Challehgers; Modena, C.F., da Porto, M.R.V., Eds.; CRC Press-Taylor \& Francis Group: London, UK, 2016; pp. 441-449. ISBN 978-1-138-02999-6.

17. Nobili, A. Durability assessment of impregnated Glass Fabric Reinforced Cementitious Matrix (GFRCM) composites in the alkaline and saline environments. Constr. Build. Mater. 2016, 105, 465-471. [CrossRef]

18. Nobili, A.; Signorini, C. On the effect of curing time and environmental exposure on impregnated Carbon Fabric Reinforced Cementitious Matrix ( CFRCM ) composite with design considerations. Compos. Part B 2017, 112, 300-313. [CrossRef]

19. Franzoni, E.; Santandrea, M.; Gentilini, C.; Fregni, A.; Carloni, C. The role of mortar matrix in the bond behavior and salt crystallization resistance of FRCM applied to masonry. Constr. Build. Mater. 2019, 209, 592-605. [CrossRef]

20. Donnini, J.; Bompadre, F.; Corinaldesi, V. Tensile behavior of a glass FRCM system after different environmental exposures. Processes 2020, 8, 1074. [CrossRef]

21. Spelter, A.; Bergmann, S.; Bielak, J.; Hegger, J. Long-term durability of carbon-reinforced concrete: An overview and experimental investigations. Appl. Sci. 2019, 9, 1651. [CrossRef]

22. Butler, M.; Mechtcherine, V.; Hempel, S. Durability of textile reinforced concrete made with AR glass fibre: Effect of the matrix composition. Mater. Struct. 2010, 43, 1351-1368. [CrossRef]

23. Spelter, A.; Bielak, J.; Will, N.; Hegger, J. Long-term durability of textile reinforced concrete. In Proceedings of the 5th International fib Congress: Better Smarter, Stronger, Melbourne, Australia, 7-11 October 2018; pp. 1922-1932.

24. Colombo, I.G.; Colombo, M.; Prisco, M. Tensile behavior of textile reinforced concrete subjected to freezing-thawing cycles in un-cracked and cracked regimes. Cem. Concr. Res. 2015, 73, 169-183. [CrossRef]

25. Al-Lami, K.; D'Antino, T.; Colombi, P. Durability of fabric-reinforced cementitious matrix (FRCM) composites: A review. Appl. Sci. 2020, 10, 1714. [CrossRef]

26. De Munck, M.; El Kadi, M.; Tsangouri, E.; Vervloet, J.; Verbruggen, S.; Wastiels, J.; Tysmans, T.; Remy, O. Influence of environmental loading on the tensile and cracking behaviour of textile reinforced cementitious composites. Constr. Build. Mater. 2018, 181, 325-334. [CrossRef]

27. Pekmezci, B.Y.; Arabaci, E.; Ustundag, C. Freeze-thaw durability of lime based FRCM systems for strengthening historical masonry. Key Eng. Mater. 2019, 817, 174-181. [CrossRef]

28. Keskinateş, M.; Beglarigale, A.; Yazıcı, H. The effect of freeze-thawing on steel fiber-matrix bond characteristics of cement based composites. In Proceedings of the Second International Conference on Advances in Civil Structural and Mechanical Engineering (CSM 2014), Birmingham, UK, 16-17 November 2014; pp. 157-161.

29. Dalalbashi, A.; Ghiassi, B.; Oliveira, D.V. Freeze-thaw durability of glass textile-reinforced mortar composites. In Brick and Block Masonry_From Historical to Sustainable Masonry; Taylor \& Francis Group: Kraków, Poland, 2020.

30. Butler, M.; Mechtcherine, V.; Hempel, S. Experimental investigations on the durability of fibre-matrix interfaces in textilereinforced concrete. Cem. Concr. Compos. 2009, 31, 221-231. [CrossRef]

31. Kong, K.; Mesticou, Z.; Michel, M.; Si Larbi, A.; Junes, A. Comparative characterization of the durability behaviour of textilereinforced concrete (TRC) under tension and bending. Compos. Struct. 2017, 179, 107-123. [CrossRef]

32. Silva, F.D.A.; Butler, M.; Hempel, S.; Toledo Filho, R.D.; Mechtcherine, V. Effects of elevated temperatures on the interface properties of carbon textile-reinforced concrete. Cem. Concr. Compos. 2014, 48, 26-34. [CrossRef]

33. Strauss Rambo, A.D.; Yao, Y.; de Andrada Silva, F.; Dias Toledo Filho, R.; Mobasher, B. Experimental investigation and modelling of the temperature effects on the tensile behavior of textile reinforced refractory concretes. Cem. Concr. Compos. 2017, 75, 51-61. [CrossRef] 
34. Donnini, J.; De Caso y Basalo, F.; Corinaldesi, V.; Lancioni, G.; Nanni, A. Fabric-reinforced cementitious matrix behavior at high-temperature: Experimental and numerical results. Compos. Part B Eng. 2017, 108, 108-121. [CrossRef]

35. Tlaiji, T.; Vu, X.H.; Ferrier, E.; Si Larbi, A. Thermomechanical behaviour and residual properties of textile reinforced concrete (TRC) subjected to elevated and high temperature loading: Experimental and comparative study. Compos. Part B Eng. 2018, 144, 99-110. [CrossRef]

36. Liu, S.; Rawat, P.; Chen, Z.; Guo, S.; Shi, C.; Zhu, D. Pullout behaviors of single yarn and textile in cement matrix at elevated temperatures with varying loading speeds. Compos. Part B Eng. 2020, 199, 108251. [CrossRef]

37. Kapsalis, P.; El Kadi, M.; Vervloet, J.; De Munck, M.; Wastiels, J.; Triantafillou, T.; Tysmans, T. Thermomechanical behavior of textile reinforced cementitious composites subjected to fire. Appl. Sci. 2019, 9, 747. [CrossRef]

38. Xu, S.; Shen, L.; Wang, J. The high-temperature resistance performance of TRC thin-plates with different cementitious materials: Experimental study. Constr. Build. Mater. 2016, 115, 506-519. [CrossRef]

39. Ombres, L.; Ior, A.; Mazzuca, S.; Verre, S. Bond analysis of thermally conditioned FRCM-masonry joints. Meas. J. 2018, 125, 509-515. [CrossRef]

40. Maroudas, S.R.; Papanicolaou, C.G. Effect of High Temperatures on the TRM-to-Masonry Bond. Key Eng. Mater. 2017, 747, 533-541. [CrossRef]

41. Homoro, O.; Vu, X.H.; Ferrier, E. Experimental and analytical study of the thermo-mechanical behaviour of textile-reinforced concrete (TRC) at elevated temperatures: Role of discontinuous short glass fibres. Constr. Build. Mater. 2018, 190, 645-663. [CrossRef]

42. Halvaei, M.; Jamshidi, M.; Latifi, M.; Ejtemaei, M. Effects of volume fraction and length of carbon short fibers on flexural properties of carbon textile reinforced engineered cementitious composites (ECCs); an experimental and computational study. Constr. Build. Mater. 2020, 245, 118394. [CrossRef]

43. Yun-tao, H.; Shi-ping, Y.; Yu-lin, Y.; Shan, L. Research on chloride diffusion and flexural behavior of beams strengthened with TRC subjected to dry-wet cycles. Constr. Build. Mater. 2019, 229, 116906. [CrossRef]

44. Reza, H.; Ozbakkaloglu, T. Synthetic fibers for cementitious composites: A critical and in-depth review of recent advances. Constr. Build. Mater. 2019, 207, 491-518. [CrossRef]

45. Hinzen, M.; Brameshuber, W. Influence of matrix composition and short fibres on the workability of fine grained fibre concrete. In International RILEM Conference on Material Science; Brameshuber, W., Ed.; RILEM: Aachen, Germany, 2010; Volume 1, pp. 131-140.

46. de Souza, L.O.; de Souza, L.M.S.; de Andrade Silva, F. Mechanical autogenous recovery and crack sealing of natural curauá textile reinforced concrete. Constr. Build. Mater. 2020, 235, 117476. [CrossRef]

47. Mobasher, B.; Peled, A.; Pahilajani, J. Pultrusion of fabric reinforced high flyash blended cement composites. In Proceedings of the World Of Coal Ash, Lexington, KY, USA, 11-15 April 2005; pp. 1473-1482.

48. Triantafillou, T. (Ed.) Textile Fibre Composites in Civil Engineering; Woodhead Publishing: Sawston, UK, 2016; ISBN 978-1-78242446-8.

49. Lieboldt, M.; Mechtcherine, V. Capillary transport of water through textile-reinforced concrete applied in repairing and/or strengthening cracked RC structures. Cem. Concr. Res. 2013, 52, 53-62. [CrossRef]

50. Bentur, A.; Yardımc1, M.Y.; Tirosh, R. Preservation of telescopic bonding upon aging of bundled glass filaments by treatments with nano-particles. Cem. Concr. Res. 2013, 47, 69-77. [CrossRef]

51. Dvorkin, D.; Poursaee, A.; Peled, A.; Weiss, W.J. Influence of bundle coating on the tensile behavior, bonding, cracking and fluid transport of fabric cement-based composites. Cem. Concr. Compos. 2013, 42, 9-19. [CrossRef]

52. Hinzen, M.; Brameshuber, W. Improvement of Serviceability and Strength of Textile Reinforced Concrete by using Short Fibres. In Proceedings of the 4th Colloquium on Textile Reinforced Structures, Dresden, Germany, 3-5 June 2009; pp. $261-272$.

53. Nadiv, R.; Peled, A.; Mechtcherine, V.; Hempel, S.; Schroefl, C. Micro- and nanoparticle mineral coating for enhanced properties of carbon multifilament yarn cement-based composites. Compos. Part B Eng. 2017, 111, 179-189. [CrossRef]

54. Mechtcherine, V.; Lieboldt, M. Permeation of water and gases through cracked textile reinforced concrete. Cem. Concr. Compos. 2011, 33, 725-734. [CrossRef] 